\title{
Applying Principles of Sociotechnical Systems onto Working Environment Research'
}

I Ole Jacob Thomassen²

PhD, School of Business, Department of Business, History and Social Sciences, University of South East Norway

I Kristin Heggen

Professor, Dean, Faculty of Medicine, University of Oslo, Norway

I Roger Strand

Professor, Centre for the Study of Sciences and the Humanities, University of Bergen, Norway

\begin{abstract}
The sociotechnical system approach induced a consistent system thinking into the Scandinavian working life research. Workers'social and psychological needs and technical/systemic conditions were seen as deeply interdependent. However, a distinct field of working environment research, dominated by individual and psychological perspectives, has developed. Indeed, working life itself has undergone substantial transformations. In the shift from first to second modernity (sensu Ulrich Beck), new phenomena (risks) have emerged that challenge workers' health. This paper discusses the potential of the sociotechnical approach to inspire the specific field of working environment research. Sociotechnical ideas are concerned about the organizational aspects of the working environment and this can challenge the dominance of individual and psychology-centred research. However, it is also necessary to renew the sociotechniocal tradition from within. We suggest a general process of a reflexive modernization of sociotechnical ideas and a stronger connection to the 'double-hermeneutic' as an epistemological outset.
\end{abstract}

\section{KEY WORDS}

Reflexive modernization / second modernity / sociotechnical systems / working environment research

\section{Introduction:The Sociotechnical Approach and Working Environment Research}

riginally developed at the Tavistock Institute of Human Relations in England (Engelstad, 1970; Thorsrud \& Emery, 1969; Trist \& Bamforth, 1951), the sociotechnical systems (STS) approach can be summarized as an ambition to design organizations in ways that successfully integrate technical/technological systems with the social/ human system. These systems are seen as deeply dependent on each other. This combined

\footnotetext{
${ }^{1}$ You can find this text and its doi at https://tidsskrift.dk/njwls/index.

${ }^{2}$ Høgskolen i Sørøst-Norge, pb. 235, 3603 Kongsberg, Norway, E-mail: ojt@hbv.no.
} 
human- and system-centeredness was largely taken up in the Nordic countries (Thorsrud, 1984), and in Norway, the Industrial Democracy Project incorporated and developed the STS ideas, especially that of direct participation. The general framework of STS soon expanded to a 'social movement' (Hvid, 2014, p. 127) and is described as a general principle of job design. Nowadays, STS is associated with job design concepts as 'workplace innovation', 'quality of working life', 'High Performance Work Systems', 'Workplace Innovation,' and 'Sustainable Work Systems' (Hvid, 2014). The dimension of STS that we explore in this paper is what we think of as a distinct epistemological approach in STS, concerning how psychosocial working life phenomena are approached. According to Trist (1981), STS is founded in a principle of an 'operative system'-in contrast to a 'regulative system'. This means that the system, the organization, is not seen as something that shall be regulated so that, that is, appliance of technology shall protect workers from the ills of technology. The idea of the operative system implies that the need of the system and the need of workers are somehow interdependent and that the important thing is to empower workers so that they can participate in the design and implementation of systems. Applied to the field of psychosocial working environment, the ideas of the operative system thinking would imply that the psychosocial experiences are not something, which should be protected, but rather indicators of the need for improvement of the organization. Which then is the entity that should get the attention of the sociotechnical researcher.

While working environment research in Scandinavia originally was attached to a comprehensive and system-oriented approach, to an STS approach so to speak (Hernes, 2010) working environment research has established itself as an autonomous research field, consisting of a multitude of research perspectives and traditions. At the same time, society and working life have changed dramatically, generating new challenges for workers and organizations, in what we, with reference to the sociologist Ulrich Beck, label second modernity (Beck, 2000; Beck \& Lau, 2005). There are two research questions in this article. The first is about how STS can inspire a move toward a more system-oriented research within current working environment research. The second and related question concerns how STS would need to renew itself to properly meet challenges in postindustrial working life. Section 1 of this theoretical/conceptual paper will discuss the first question and review some general tendencies within work environment research. Although STS often is referred to as a job design concept, it also represents a more general philosophy of work, according to Trist: 'I use the term philosophy advisedly to indicate that far more is involved than methods or techniques' (Trist 1981, p. 44). It is the general philosophical framework of STS we believe to be timely and important to the field of working environment research. In Section 2, we suggest that it also is necessary with a renewal of the STS from within, notably because psychosocial working life phenomena themselves are changing within second modernity.

\section{Section I: STS as a Response to Individual and Psychological Research Perspectives in Working Environment Research}

\section{Developments within Working Environment Research}

There has been a strong growth and differentiation of research related to working life over the years, implying that the distinct Nordic or Scandinavian perspective, arising in 
the 1960s and 1970s, has been exposed to other disciplines and traditions inside as well as outside of Scandinavia. Hasle and Sørensen (2013) contrast the Nordic perspective with three other working life research traditions: human resource management research (HRM), occupational health and safety research (OHS), and labor process theory research (LPT) (Hasle \& Sørensen, 2013, p. 22). HRM research builds upon the human relations movement, which is concerned with strategic management of workers' 'human needs'. OHS research is related exclusively to working environment factors (chemical, physical, social, etc.), while LPT research builds upon a critical and Marxist conception of the relationship between workers and organizations.

In the rather complex picture of what characterizes working life research, it seems clear, however, that working environment research has established itself as a relatively autonomous field and that this is rather synonymous with what Hasle and Sørensen labeled OHS research. Topics covered within this field include stress/distress (Cooper and Cartwright 1994, Karasek and Theorell 1990), fatigue (Hanson et al., 2011, Leineweber et al., 2013), burnout (Leiter \& Maslach, 1988; Leiter \& O’Neill, 1991; Schaufeli \& Enzmann, 1998; Schaufeli et al., 1993), depression (Theorell et al., 2015), and conflicts/ mobbing (Einarsen \& Nielsen, 2015; Nielsen et al., 2014; Reknes et al., 2014). Several studies point to this research as characterized by a development toward an increasingly evidence-based approach to working environment phenomena (Cox et al., 2007; Polanyi et al., 2005; Theorell, 2006; Willadssen, 2014), and this development has met substantial critique. A central part of this critique is that evidence-driven concepts, like Karasek and Theorell's (1990) demand-control-support model or Siegrist's effort-reward-imbalance model, lack an organizational focus (Theorell, 2006). Väänänen et al. (2012) argue that much of the research within this field has drifted from a 'social reform' agenda to more individually and psychologically oriented research:

\begin{abstract}
Work stress emerged as a concept when major social changes occurred in the $1960 \mathrm{~s}$ and early 1970s, but the debate soon drifted away from the social reform of work life and started to focus on micro-level aspects. This turn was in line with the traditional methodological individualism of psychomedical sciences and the general individualization tendencies of the era (...). Consequently, several dimensions of work became characterized by psychological concepts, and discourses describing work-related experiences changed. Overall, the development of work stress research was part of the growing rationalization of emotional and mental health-related aspects of work life and occupational health. These aspects became important not only for researchers but also for employers, politicians, and ordinary citizens. Over a 40-year period, a new discursive, institutional, intellectual, and subjective space was born, in which workers' mental energy - and its determinants and consequences - became the centre of attention. (Väänänen et al., 2012, p. 793)
\end{abstract}

This change in work environment research has been accompanied by a change in practices to improve the work environment. Examples include the increasing use of therapeutic methods like mindfulness-based stress reduction programs (MBSR), positive psychology programs like the 'solution-oriented approach'-LØFT, in Norwegian (Langslet, 1999), and mental capacity training like meditation (Shiba, 2015) among workers. Mindfulness programs and other therapeutic programmes, such as work-focused cognitive behavioral therapy (Reme et al., 2015), have even been included in the Norwegian Labour and 
Welfare Administration's (NAV) repertoire to reintegrate people with mental disabilities into work (Idébanken, 2015).

\section{STS and The Principle of 'Operative Systems' as an Alternative}

These processes of differentiation and separation of working environment research over the years have weakened the organizational and systemic focus. More consistent systemoriented approaches should be developed, linking the subjective/individual experiences, to systemic, organizational, and even societal conditions:

There is a need to create greater opportunities for both workers and employers to participate in the design and conduct of research aimed at understanding how work experiences have changed and how those changes affect health (in all its variations) of workers and workplace. (Polanyi et al., 2005, p. 107)

Enehaug proposed that, within the framework of STS, psychosocial experiences (typically explored through Karasek and Theorells Job-Demand-Resoruces model) should be reconnected to the change-oriented perspective of organizational learning: 'Together, these perspectives provides a more nuanced understanding of how organization, the individual and structure interacts in different situations and under varying conditions' (Enehaug, 2014, p. 80). The epistemological distinctness of STS, which can be derived from the principle of the operative system, is a useful conceptual model for this. Trist (1981) explains regulative systems as '... concerned directly with the psychosocial ends of their members (...). Many such organizations employ technologies as adjuncts (...)' (Trist, 1981, p. 12). Within the perspective of a regulative system, psychosocial needs become ends in themselves for which organizations should provide and protect. Operative systems such as sociotechnical organizations, however, see psychosocial needs not as ends in themselves, but as a system to which the technical system must adopt to: 'By contrast, organizations which are primarily socio-technical are directly dependent on their material means and resources for their outputs' (Trist, 1981, p. 12). From this, we think that the epistemological distinctness within STS regarding subjective and individual experiences related to the social and psychological domain is about seeing these not as targets in themselves, upon which the organization should be designed around. They are first and foremost indications of the overall functioning of the organization. Therefore, this epistemological principle deals with the 'human factor' not as an end in itself, but as indications of the structural (technical) conditions. Following, 'poor conditions' will indicate a need for technological, systemic, and organizational change-and not a change in the subject.

\section{Section 2:The Need to Renew STS from within, with The Coming of Second Modernity Working Life}

We have argued above that the basic principles of STS (linked specifically to the operative system thinking) provide a suitable framework for exploration of psychosocial phenomena and an inspiration to working environment research. Nevertheless, it is important to understand the context in which STS was developed and compare it to the 
context of contemporary working life. A hermeneutic understanding of STS is useful for identifying why and how it is necessary to renew STS from within. That STS has to develop and renew itself is not a new debate (Hvid, 2014; Kamp et al., 2014). In this section, we address some specific issues of renewal in order that STS may even better address and inspire work environment research. We take our approach to be consistent with the open-system oriented ideology within STS itself: 'Socio-technical phenomena are contextual as well as organizational' (Trist, 1981, p. 11).

\section{STS as Answer to Challenges in The Industrial Working Life Paradigm}

It is useful to recall the historical context of Scandinavia in the 1960s, both politically and in terms of working life. On the macro level, the 1950s and 60s was the heyday of the 'labour party state' (Slagstad, 2001) in Denmark, Norway, and Sweden, dominated by the project of jointly rebuilding society after WWII. In terms of working life, the 'joint effort' implied a shared interest between employers, workers, and government in improving industrial working conditions (also as a means to increase productivity), installing democracy at the workplace (and in society) and, following from this, avoiding or ameliorating work conflicts. This was a post-Marxist period in which not only negative consequences of an industrial working life were to be solved, but also the time for identifying how working life represents an arena for human growth at the personal level-and for building democracy at the societal level. As such, the sociotechnical perspective provided a solution, both as an ideological framework and as a research paradigm.

From a sociological point of view, Scandinavian working life in the 1950s and 60s was not only post-Marxist but may also be seen as belonging to what has been called 'first modernity' (Beck, 2000; Beck \& Lau, 2005), a period dominated by a belief in progress and optimistic views on societal and historical development, on technology and on the role of research: 'The first modernity gave a series of institutionalized answers to the problems facing society: more and better technology, more and better scientific research, more and better functional differentiation' (Beck, 2000, p. 22). This belief in progress is clearly visible in STS lines of thoughts, where a joint interest between workers, employers, and society is an underlying and essential premise. And in which technology is possible to control and use beneficially. According to Beck, such a belief is based on an underlying assumption of risks (as well as potentials for growth), as transparent and visible. During the first modernity, risks were, in a sense, self-evident:

These are 'basic premises' in another sense, too. For they are seen throughout society as institutionally and individually self-evident - as a kind of 'second nature'. (Beck, 2000, p. 20)

When analysing STS in light of the concept of first modernity, some general assumptions about risks are identifiable. Within STS (as in first modernity in general), risks in working life can be described as one-dimensional, vertical, and explicit-and, to which there are what we call 'obvious' solutions. Trist's (1981) description of the technocratic bureaucracy and how this undermines both necessary organizational innovation and human development can be seen as an example of a one-dimensional risk-description. The 'one-man-one-job' principle inherent in the technocratic bureaucracy is assumed to be an organizational configuration with little legitimacy. STS contested this principle 
and provided new answers, such as self-regulation and worker autonomy. That risks are conceived of as vertical is about how risks are seen as unevenly distributed, primarily according to a hierarchic structure, formal positions, and the degree of autonomy, which follows this. This would mean that a position/role with a high degree of autonomy is assumed to have fewer and less serious risks, than a position with a low degree of autonomy. Further, risks are explicit in the sense that they are attached to threats in the physical and/or psychological infrastructure, to environmental factors etc. Risks in the working environment are, as such, something that workers are exposed to from external sources and are as such directly assessable. Finally, finding solutions for onedimensional, vertically distributed, and explicit risks can be described as 'obvious'. This does not mean that solutions are simple, but that solutions in general can be thought of as 'opposites to a prevailing condition'. The problem of 'one-man-one-task' can be solved by a principle of 'one-man-several-tasks'. The problem of low autonomy can be solved by responsible autonomy. Lack of democracy at the workplace can be compensated for by installing more democratic work forms.

\section{New Challenges in Postindustrial Working Life: Second Modernity Risks}

With the coming of a postindustrial working life, new challenges rose for workers, many of which are assumed to have a close relation to the coming of a flexible and neoliberal working life paradigm (Allvin, 2006; Bauman et al., 2006; Giddens, 1991; Sennett, 1998). The concepts 'flexible' and 'neoliberal' to some degree differ in terms of the implications for workers but have similarities in the general descriptions of the drivers behind the postindustrial working life. The flexible paradigm is described as a general weakening of traditional structures and functions in working life, both at an institutional and individual level, inducing constant changes and transitions and the creation of boundaryless organizations (Allvin, 2006). Hence, work tasks and forms have become temporary, putting extensive pressure on workers adaptive skills. Different consequences of the flexible paradigm have been spelled out, ranging from Sennett's diagnostic claim of an eroded personal character (Sennett, 1998), to more modest descriptions of how flexible working life creates disturbances in the interface between the spheres of work and home (reflected in the Work Life Balance concept) or that work can create honey-traps (Sørensen \& Grimsmo, 1993).

Critics of neoliberalism are concerned with different sort of challenges that arises in the aftermath of New Public Management (NPM). The New Management Discourse, seen as a central feature of NPM, is described to reinforce monitoring, control, and inspection of workers and, hence delimit professional autonomy and even sometimes lead to deprofessionalization (Broadbent et al., 1997; Christensen \& Lægreid, 2007; Kärreman et al., 2002; Klikhauer, 2013). Much of the same critique is directed towards Lean Production, which is even criticised for endangering ground-floor workers health and well-being, with its reinitiating of specialization, standardization, and routinization in professional work (Hasle et al., 2012; Landsbergis \& Schnall, 1999; Oudhuis \& Tengblad, 2013). Another string of critique of neoliberalism is concerned with how deregulation and apparent 'freedom' at the work-task level of the single worker, which also is seen as a feature of NPM, is paired with new forms of discipline (Gordon et al., 1991; Miller \& Rose, 1988; Rose, 1999). This is basically about how control is achieved by workers controlling themselves 
from the inside. An example of a new sort of risk, which is constructed from these new tensions are what Allvin (2006) labels 'individual compensating techniques'. This concept describes how professional workers within welfare institutions tend to prioritize customer or patient needs prior to own health. In situations where the organizational premises are insufficient, workers will stretch their own limits to compensate. Vike et al. (2002) discuss how poor organizational and systemic conditions generate personal and bodily imprints and call this phenomenon a 'bodylization of structural incapacity'. Thomassen's (2013) research on the phenomenon of integrity indicates that workers' main strategy for experiencing doing 'good, professional work' (which is conducive to experiencing integrity in work) is to gamble with their own physical and mental health, a strategy that resembles an individual compensating technique. From a discursive point of view, the phenomenon of individual compensating technique can be analyzed in relation to the Foucauldian concept of discipline (Gordon et al., 1991), where control is exercised as much from within-from incorporated beliefs-as from an external source of power. Rose (Miller \& Rose, 1988; Rose, 1999) points out how also 'soft' ways of organizing work, typical for neoliberalism, have a disciplining effect on workers and creates 'responsibilization'. Control comes from inside, from the workers' own willingness to work because they see this as beneficial to themselves-or to the client, patient, or customer.

What stands out is that postindustrial working life in radical new way generates new sorts of risks, different (in an ontological sense) than those generated in the industrial area from which STS originated. Furthermore, this change corresponds closely to Beck's description of how risks manifest in second modernity. Second modernity '(...) refers to the foreseeable and conceptually clear principle of blurring or fuzziness which marks the picture of work, society and politics in the second modernity (...)' (Beck, 2000$, p. 70$)$. The risk regime as such therefore consists of risks that are paradoxical, and to a large degree, individual.

Compared to our description of risks in first modernity, risks in the second modernity can be described as multidimensional, horizontally distributed, and implicit—and, with what we will call unclear and complex solutions. Multidimensional risks are risks that cannot be easily qualified as good or bad, positive or negative. These are risks that represent opportunities as well as problems for workers. The situation for the semiprofessionals/professionals and the phenomenon of self-exploitation, described above, is a good example Second, risks are to a large extent distributed horizontally as much as vertically. Risks are not distributed according to the workplace hierarchy. Again, the situations for the semi-professional and professional workers are a good example. Despite a relative high degree of autonomy in work and a relative high degree of freedom to decide how work is to be done, reduction of autonomy over work more generally places professional in the epicenter for typical second-modernity risks. The implicit aspect of risks relates to the phenomenon responsibilization, as described above, which is about risks coming from the inside more than from the outside. Another useful concept referring to this is that of 'prudentialism', which means a removal of the core idea that individuals can best be regulated through collectivist risk management, it 'throws back upon the individual the responsibility for managing risks (O’Malley, 1996, p. 197). Finally, because risks are multidimensional, horizontally distributed, and implicit, solutions are unclear: Reducing professional autonomy from semi-professional/professional workers, in order to minimize self-exploitation, might be perceived of as a professional insult, threatening professional dignity (Allvin, 1999). From this, the following table illustrates 
characteristics of the general differences between problems/risks and solutions in first versus second modernity:

Table I Risks and solutions in first versus second modernity

\begin{tabular}{lll}
\hline & First modernity & Second modernity \\
\hline Problems/risks & $\begin{array}{l}\text { One-dimensional, vertically } \\
\text { distributed, explicit }\end{array}$ & $\begin{array}{l}\text { Multidimensional, horizontally } \\
\text { distributed, implicit }\end{array}$ \\
\hline Solutions & 'Obvious' problems, 'obvious' & $\begin{array}{l}\text { Complex problems, unclear } \\
\text { solutions }\end{array}$ \\
\hline
\end{tabular}

The new risk dynamic makes the power redistribution strategies from the first modernity irrelevant, if not counterproductive. If the problem is self-exploitation, a STS first-modernity solution of giving 'more responsible autonomy to the worker' might indirectly undermine a strategy that relies on individual compensating techniques.

\section{STS as a Model for Working Environment Research-but, with the Need of a 'Reflexive Modernization'}

In line with the analysis presented above, we suggest that STS can and should be renewed by what Beck calls a 'reflexive modernization'. According to Beck (2000), the point of departure for reflexive modernization is to acknowledge that the 'products' of the first modernity might have unintended negative consequences:

In the second modernity, the process of modernization is reflexive in the sense that it has increasingly to face the unintended consequences of its own success. (...) To express this in a metaphor, we are dealing here with a 'revolution of side-effects'. (Beck, 2000, p. 21)

The new 'second modernity risks' can indeed be thought of as new sorts of disturbances and interferences between the social and technical system. As such, they can be described as 'post-industrial equivalents' to the problems in the first modernity (generated by the technocratic bureaucracy). In this way, STS can and should analyze and confront NPM as a technical system in itself, which interferes with the social/human system. Given the direct consequences that NPM has on how work is organized and how this deeply influences workers' conceptions of their work, it is relevant to see NPM as a technical system in itself.

However, if STS is to take on such a role, it might be necessary to recall and reestablish some of its critical potential. It seems that STS today largely has become a job design concept and inspired the developments of concepts like 'workplace innovation', 'quality of working life', 'High performance Work Systems', 'Workplace Innovation', and 'Sustainable Work Systems' (Hvid, 2014). In a Norwegian context, it has also become closely equated with innovation and entrepreneurship research strategies and perspectives (Gustavsen, 2010). Our point is not that principles of STS are irrelevant for such purposes. However, by taking on a role as a an 'innovation-processess-generator' or by becoming a 'job design concept', STS might gravitate toward a less critical position vis a vis working life. After all, STS was about 'going against the grain of the fifties' 
(Trist, 1981, p. 14), which were the technocratic bureaucracy. What would it mean, then, to 'go against the grains of the 2000s'?

One answer may be found by attending the different levels attended to by STS (Trist, 1981). At the level of the primary work system, defined as 'the organizational building blocks' (Trist, 1981, p. 29), it seems necessary to critically examine what key concepts like 'responsible autonomy', 'autonomous groups', 'self-regulation', and 'participant design' can and should mean today. These, together with the 'Principles of work design' (ibid, p. 31), point to typical challenges typical for the industrial era. As Hvid (2014) and Amble (2013) points to-it is of utmost importance to clarify, interpret, and also reinterpret such concepts, so that they both reflect the realities of contemporary working life and can inspire STS initiatives. At the level of the whole organizations system (the second level, according to Trist), we wish to highlight the striking importance of this level in itself for assessing the realities of contemporary working life. One of the core characteristics which marks the postindustrial working life are how both public and private organizations on a very broad basis have become global and transnational (Christensen \& Lægreid, 2007; Christensen et al., 2009; Kettl, 2006; Wallerstein, 2000). A central feature of neoliberal governance within public sector is that the concept of NPM has become a general solution for western, modern countries. Further, a hallmark of NPM itself is increased political steering, often combined with reduced autonomy at level of the single organization and for workers (Christensen \& Lægreid, 2008). In the definition of the whole organizations system, Trist refers to Schon's concept of the 'Loss of the stable state' (Trist, 1981, p. 39) as a phenomenon to which STS should respond. This logic appears even more important today, as the organizational meta-structure has become the order of the day. A postindustrial resemblance of Schon's concept of the lost stable state, could, that is, be the concept of the 'competition state' ('konkurrencestaten') (Pedersen, 2011) referring to how competition in and between states, has substituted the traditional, national welfare state. To be able to develop fits between people and systems today, we believe it is necessary to critically analyze how such transnational trends and paradigms impacts on how organizations are structured, and how this in subtle ways affects conditions for workers on the ground floor. Hence, Trist's last level, the macrosocial level, is of more importance than ever and should be seen in close connection the second level. This macrosocial level has to do with developments of new technologies or paradigm shifts in production, and the relevancies of this is, as with the whole organizations system level, growingly important.

Overall, second modernity working life bears with it challenges that structurally resemble the challenges, which the technocratic bureaucracy represented many years ago-albeit in different forms and fashions. As we have argued, second modernity risks have some other characteristics than first modernity risks. Within what we see as a reflexive modernization of STS lies that it should re-establish its critical core and take on a more visible role and mission of being a counter-response to some of the prevailing and dominating tendencies in modern working life.

\section{STS and a Connection to Double Hermeneutics as Epistemological Outset}

Another basic challenge in the transition from first to the second modernity concerns the question of how to generate relevant knowledge on the complex and paradoxical 
character of working environment problems. This question concerns epistemology. Double hermeneutics may constitute a promising point of departure for an epistemological renewal of STS. The 'principle of double hermeneutics' (Giddens, 1991, 1993) acknowledges that representations of reality are themselves socially constructed and that people's descriptions, or official descriptions of a field, should be assessed as social constructs rather than a reflection of some kind of objective reality: 'Sociology deals with a universe which is already constituted within the frames of meaning by social actors themselves, and reinterprets these within its own theoretical schemes, mediating ordinary and technical language' (Giddens, 1993, p. 70). Hence, double hermeneutic analysis implies that the researcher is dependent on doing a reflexive, critical analysis of the phenomenon in question.

For STS research, this would mean to move beyond the prima facie appearances and common sense perceptions of working life phenomena and replace them with a critical analysis of the phenomena under study. We have already noted the development of an individualistic and psychological research paradigm within working environment research (Väänänen et al., 2012). This development can only partly be balanced by more structurally orientated research; it also calls for active epistemological resistance toward the discourses, which frame contemporary working life problems. As an example: If one turns to how the Norwegian State formulates basic work environment challenges, a rather clear picture emerges of a rise in psychological problems at the workplace. NAV states that there has been a significant growth in mental disabilities over the last several years, and that this diagnosis is the principal cause of work disability. In 2013, 32.4\% of people with work disability were diagnosed with mental disability (Norges Arbeids- og Velferdsforvaltning, 2015). The Norwegian Directorate of Health thus pronounces:

Among persons excluded from working life, people with psychological suffering constitute an increasingly large group of the total number of persons excluded from working life (...). Norwegian and other international studies document that $30-50 \%$ of the adult population will suffer from at least one psychological disease during their lifetime. (Helsedirektoratet, 2016)

A first-order interpretation would suggest that contemporary working life generates new problems, which are centered on an individual-psychological axis. What appears to be at stake is, then, primarily workers psychological health. Indeed, a more psychologically and individually oriented research agenda, as Väänänen et al. depict as typical, might even seem as a 'natural response' to such: 'We need more research on psychological problems at the workplace'. Such an approach might even have support in a cultural climate, in which psychological models has gained substantial support. Madsen $(2010,2011)$ has made the argument that Norwegian society can be characterized as a 'therapeutic culture', while Tunestad (2014) claims that a 'psychological work ethic' has become typical in Sweden. From the position of a second-order interpretation-applying double hermeneutics-this conceptualization becomes, however, possible to contest. Instead of depicting subjectively experienced working life as psychological phenomena, these can be depicted as organizational and systemic in their character, that is, as craftwork dilemmas for semi-professional and professional workers, generated by the tension between professionals' own expectations of quality versus bureaucratic regulation of work (Thomassen, 2013). As we see it, the field of psychological work environment research represents an almost 'ideal' field for 
prevalence of second modernity risks. Many of these phenomena, and their consequences, are paradoxical and ambiguous, and need to be interpreted before solutions can be found to problems in the workplace. To apply double hermeneutics would be to reinterpret and not only to confirm the first-order interpretation of work environment phenomena, as they appear either at the workplace level or in the public discourse.

Table II A model for a reflexive modernization of STS — double hermeneutics included

\begin{tabular}{lll}
\hline & First modernity & Second modernity \\
\hline Problems/risks & $\begin{array}{l}\text { One-dimensional, vertically } \\
\text { distributed, explicit }\end{array}$ & $\begin{array}{l}\text { Multidimensional, horizontally } \\
\text { distributed, implicit }\end{array}$ \\
\hline Solutions & 'Obvious' problems, 'obvious' & $\begin{array}{l}\text { Complex problems, unclear } \\
\text { solutions }\end{array}$ \\
\hline Assessment strategy & First-order interpretation & $\begin{array}{l}\text { Second-order interpretation; } \\
\text { double-hermeneutics }\end{array}$ \\
\hline
\end{tabular}

Double hermeneutics can provide outsets for a system-oriented critique of contemporary organizations.

\section{Conclusion}

Is STS best suited for tackling the problems of the 'first modernity working life'? Are we ourselves nostalgic when we address the need for renewal? We think not. STS ideas are rooted in a practical vision, which is to transform organizations, people, and society. This ambition is important and offers a corrective and practical alternative to the psychological-individual turn that dominates the contemporary field of working environment research. We also see STS as an important alternative to the more academic and dogmatic perspectives fostered within critical management studies or contemporary sociology dealing with working life issues. While these approaches offer important perspectives and, to a large degree, build upon a strategy of double hermeneutics, they struggle with practical relevance, as Burawoy (2004) points out. In other words, they do not give organizations and workers concrete steps to implement better working conditions. A renewal of STS, by a reflexive modernization and by making doublehermeneutics more central-so that STS is adjusted to grasp the phenomena of second modernity working life better-provides a promising middle way. After all, the term 'socio-technical' points to a specific organizational framework in which questions of organizing are the main concern, and this should represent an important contribution to contemporary working environment research.

\section{Literature}

Allvin, M. (2006). Gränslöst arbete: socialpsykologiska perspektiv på det nya arbetslivet [Boundaryless Work: Socialpsychological Perspectives on The New Working Life]. Malmö: Liber. 
Allvin M. (2006). Gränslöst arbete: socialpsykologiska perspektiv på det nya arbetslivet, Malmö: Liber.

Amble, N. (2013). Autonomy and Control when Working with Humans - A Reflection on Sociotechnical Concepts. Nordic Journal of Working Life Studies, 3(4): 45-62.

Bauman Z, Nygård M, Kolstad H, et al. (2006). Flytende modernitet [Liquid Modernity] Oslo: Vidarforl.

Beck, U. (2000). The brave new world of work. Cambridge: Polity Press.

Beck, U., \& Lau, C. (2005). Second Modernity as a research agenda: theoretical and empirical explorations in the 'meta-change' of modern society. British Journal of Sociology, 56(4): 525-557.

Broadbent J, Dietrich M and Roberts J. (1997). The End of the Professions? The Restrucuring of Professional Work, London: Routledge.

Burawoy, M. (2004). The world needs public sociology. Sosiologisk tidsskrift (3): 256-272.

Christensen T and Lægreid P. (2007). Transcending new public management: the transformation of public sector reforms, Aldershot: Ashgate.

Christensen T and Lægreid P. (2008). Trancending New Public Management - the Increasing Complexity of Balancing Control and Autonomy. The Third Conference on Public Management in 21st century: Oppurtunities and Challenges. China.

Christensen T, Lægreid P, Roness PG, et al. (2009). Organisasjonsteori for offentlig sektor, [Organizational Theory for Public Sector] Oslo: Universitetsforl.

Cooper, C. L., \& Cartwright, S. (1994). Healthy Mind; Healthy Organization-A Proactive Approach to Occupational Stress. Human Relations, 47(4): 455-471. doi: http://dx.doi. org/10.1177/001872679404700405.

Cox, T., Karanika, M., Griffiths, A., \& Houdmont, J. (2007). Evaluating organizational-level work stress interventions: Beyond traditional methods. Work \& Stress, 21(4): 348-362. doi: http://dx.doi.org/10.1080/02678370701760757.

Einarsen, S., \& Nielsen, M. (2015). Workplace Bullying as an Antecedent of Mental Health Problems: a five-year Prospective and Representative Study. International Archives of Occupational and Environmental Health, 88(2): 131-142. doi: http://dx.doi.org/10.1007/ s00420-014-0944-7.

Enehaug H. (2014). Læring i omstillingenes tid - et teoretisk innspill om arbeidsmiljø og organisasjonslæring [Teaching in Times of Organizational Change - A Theoretical Contribution on Working Environment and Organizational Learning]. Tidsskrift for Arbejdsliv 16: 69-84.

Engelstad, P. H. (1970). Teknologi og sosial forandring på arbeidsplassen. Et eksperiment i industrielt demokrati [Technology and Social Change at The Workplace]. Oslo. Tanum.

Giddens, A. (1991). Modernity and self-identity: self and society in the late modern age. Cambridge: Polity Press.

Giddens, A. (1993). New rules of sociological method: a positive critique of interpretative sociologies. Oxford: Polity.

Gordon, C., Burchell, G., Miller, P., \& Foucault, M. (1991). The Foucault effect: studies in governmentality: with two lectures by and an interview with Michel Foucault. London: Harvester/Wheatsheaf.

Gustavsen, B. (2010). Innovasjonssamarbeid mellom bedrifter og forskning: den norske modellen [Innovation and Cooperation between Organizations and Science]. Oslo: Gyldendal akademisk.

Hanson, L. L. M., Åkerstedt, T., Näswall, K., Leineweber, C., Theorell, T., \& Westerlund, H. (2011). Cross-lagged relationships between workplace demands, control, support, and sleep problems. Sleep, 34(10): 1403. doi: http://dx.doi.org/10.5665/SLEEP.1288.

Hasle, P., Bojesen, A., Langaa, P. \& Bramming, P. (2012). Lean and the working environment: a review of the Literature. International Journal of Operations \& Production Management, 32(7): 829-849. 
Hasle, P., \& Sørensen, O. H. (2013). Employees as Individually and Collectively Acting Subjects - Key Contributions from Nordic Working Life Research. Nordic Journal of Working Life Studies, 3(3): 9-30.

Helsedirektoratet. (2016). Arbeid og psykisk helse [Work and Mental Health]. Hentet 12.5.2016 2016, fra https://helsedirektoratet.no/folkehelse/psykisk-helse-og-rus/arbeidog-psykisk-helse

Hernes, G. (2010). Tilbake til samfunnet [Back to Society]. Tidsskrift for Samfunnsforskning 51:1, 9-37. (Originally published, 1981)

Hvid H. (2014). Socioteknik som samfundsforandring [Socio-Technical Systems Approach as Societal Change Agent]. Tidsskrift for Arbejdsliv 16: 126-133.

Idébanken. (2015). Idébanken - for et arbeidsliv som inkluderer. Meditasjon kan øke arbeidsgleden [The Bank of Ideas - Towards an Inclusive Working Life. Meditation might Enhance Work Zest]. Hentet 24.11.2015, fra http://www.idebanken.org/innsikt/artikler/ meditasjon-kan-oke-arbeidsgleden

Kamp A, Hasle P and Andersen Tangaard P. (2014). Revitalisering af Socioteknikken - social kapital, samarbejde og sociale relationer [To Revitalize Socio-Technical Systems TheorySocial Capital, Cooperation and Social Relations]. Tidsskrift for Arbejdsliv 16: 5-10.

Karasek, R., \& Theorell, T. (1990). Healthy work: stress, productivity, and the reconstruction of working life. New York: Basic Books.

Kettl DF. (2006). The Global Public Management Revolution: Brookings Institution Press.

Klikauer T. (2013). Managerialism: a critique of an ideology, Basingstoke: Palgrave.

Kärreman D, Sveningson S and Alvesson M. (2002). The return of the machine bureaucracy? Management control in the work settings of professionals. Management \& Organizations 32: 70-92.

Landsbergis, P. A., \& Schnall, P. (1999). The impact of lean production and related new systems of work organization on worker health. Journal of Occupational Health Psychology, 4(2): 108-130.

Langslet, G. J. (1999). LØFT: løsningsfokusert tilnœerming til organisasjonsutvikling, ledelsesutvikling og konfliktløsning [Solution Oriented Approach towards Organizational Development, Managementsupport and Conflict resolution]. Oslo: Ad notam Gyldendal.

Leineweber, C., Kecklund, G., Theorell, T., Åkerstedt, T., Alexanderson, K., \& Westerlund, H. (2013). Inflytande över arbetstiden och sjuknärvaro/sjukfrånvaro [Influence over work hours and sickness-prescence/absence] Arbetsmarknad \&Amp; Arbetsliv, 19(4): 87-99.

Leiter, M., \& O’Neill, P. (1991). The Dream Denied: Professional Burnout and The Constraints of Human Service Organizations. Canadian Psychology/Psychologie canadienne, 32(4): 547-558. doi: http://dx.doi.org/10.1037/h0079040.

Leiter, M. P., \& Maslach, C. (1988). The impact of interpersonal environment on burnout and organizational commitment. Journal of Organizational Behavior, 9(4): 297-308. doi: http://dx.doi.org/10.1002/job.4030090402.

Madsen, O. J. (2010). Den terapeutiske kultur [The Therapeutic Culture]. Oslo: Universitetsforl.

Madsen, O. J. (2011). The unfolding of the therapeutic: the cultural influence of psychology in contemporary society. Bergen: University of Bergen.

Miller, P., \& Rose, N. (1988). The Tavistock Programme: The Government of Subjectivity and Social life. Sociology, 22(2): 171-192. doi: http://dx.doi.org/10.1177/0038038588 022002002 .

Nielsen, M. B., Magerøy, N., Gjerstad, J., \& Einarsen, S. (2014). Workplace bullying and subsequent health problems. Tidsskrift for den Norske logeforening: tidsskrift for praktisk medicin, ny reekke, 134(12-13): 1233. doi: http://dx.doi.org/10.4045/tidsskr.13.0880.

Norges Arbeids- og Velferdsforvaltning. (2015). 1 av 3 uføre har psykiske lidelser [1 out of 3 has Mental Disorders]. Hentet 9.12.2015 2015, fra https://www.nav.no/no/NAV+og+samfunn/Statistikk/Pensjon+-+statistikk/Nyheter/1-av-3-uf\%C3\%B8re-har-psykiske-lidelser 
O’Malley P. (1996). Risk and responsibility. In: Andrew B, Osborne T and Rose N (eds) Foucault and political reason: liberalism, neo-liberalism and rationalities of government. Chicago: University of Chicago Press.

Oudhuis, M. \& Tengblad, S. (2013). Experiences from Implementation of Lean Production: Standardization versus Self-Management: A Swedish Case Study. Nordic Journal of Working Life Studies, 3(1): 31-48.

Pedersen OK. (2011). Konkurrencestaten [The Competition State], København: Hans Reitzel.

Polanyi, M., McIntosh, T., \& Kosny, A. (2005). Understanding and improving the health of workers in the new economy: A call for a participatory dialogue-based approach to work-health research. [Article]. Critical Public Health, 15(2): 103-119. doi: http://dx. doi.org/10.1080/09581590500144694.

Reknes, I., Pallesen, S., Magerøy, N., Moen, B. E., Bjorvatn, B., \& Einarsen, S. (2014). Exposure to bullying behaviors as a predictor of mental health problems among Norwegian nurses: results from the prospective SUSSH-survey. International journal of nursing studies, 51(3): 479. doi: http://dx.doi.org/10.1016/j.ijnurstu.2013.06.017.

Reme, S. E., Grasdal, A. L., Løvvik, C., Lie, S. A., \& Øverland, S. (2015). Work-focused cognitive-behavioural therapy and individual job support to increase work participation in common mental disorders: a randomised controlled multicentre trial. Occupational and Environmental Medicine. doi: http://dx.doi.org/10.1136/oemed-2014-102700.

Rose, N. (1999). Governing the soul. London: Free Association Books.

Schaufeli, W. B., \& Enzmann, D. (1998). The burnout companion to study and practice: a critical analysis. London: Taylor \& Francis.

Schaufeli, W. B., Maslach, C., \& Marek, T. (1993). Professional burnout: recent developments in theory and research. Washington, DC: Taylor \& Francis.

Sennett, R. (1998). The corrosion of character: the personal consequences of work in the new capitalism. New York: W. W. Norton.

Shiba, K., Nishimoto, M., Sugimoto, M., \& Ishikawa, Y. (2015). The Association between Meditation Practice and Job Performance: A Cross-Sectional Study. PLoS ONE, 10(5).

Slagstad, R. (2001). De nasjonale strateger [The National Strateges]. Oslo: Pax.

Sørensen BA and Grimsmo A. (1993). Arbeidsmiliøer i medievirksombet - kremjobb til krampa tar? [To Work in the Media Sector - Nice work until the cramp gets you], Oslo: Instituttet.

Theorell, T. (2006). New directions for psychosocial work environment research, Editorial, Scandinavian Journal of Public Health, s. 113-115. Hentet fra http://search.ebscohost. com/login.aspx? direct=true $\& \mathrm{db}=$ aph \&AN=20350331\&site=ehost-live

Theorell, T., Hammarstrom, A., Aronsson, G., Traskman Bendz, L., Grape, T., Hogstedt, C., ... Hall, C. (2015). A systematic review including meta-analysis of work environment and depressive symptoms. BMC Public Health, 15(1): 738.

Thomassen, O. J. (2013). Integritet som arbeidslivsfenomen [Integrity as a work life phenomena]. Ph.D.-Thesis, Faculty of Medicine, University of Oslo: Oslo.

Thorsrud, E. (1984). The Scandinavian model: Strategies in organizational democratization. I B. Wilpert \& A. Sorge (Red.), International yearbook of organizational democrazy (B. II, s. 85-101). Wiley.

Thorsrud, E \& Emery, F. (1969). Mot en ny bedriftsorganisasjon. Eksperimenter i industrielt demokrati, fra Samarbeidsprosjektet LO/NAF [Towards a New Organization. Experiments in Industrial Democrazy]. Oslo: Tanum

Trist EL. (1981). The evolution of socio-technical systems: a conceptual framework and an action research program, Toronto: Ontario Ministry of Labour, Ontario Quality of Working Life Centre

Trist, E., \& Bamforth, K. (1951). Some social and psychological consequences of the longwall method of coal getting. Human Relations, 4(14): 3-38. 
Tunestad, H. (2014). The Therapeutization of Work: The Psychological Toolbox as Rationalization Device during the Third Industrial Revolution in Sweden.

Vike, H., Brinchmann, A., Brinchmann, A., Haukelien, H., Kroken, R., \& Bakken, R. (2002). Maktens samvittighet: om politikk, styring og dilemmaer $i$ velferdsstaten [The counsciousness of Power: On politics, Governance and Dilemmas in the Welfare State]. Oslo: Gyldendal akademisk.

Väänänen, A., Anttila, E., Turtiainen, J., \& Varje, P. (2012). Formulation of work stress in 1960-2000: Analysis of scientific works from the perspective of historical sociology. Social Science \& Medicine, 75(5): 784-794. doi: http://dx.doi.org/10.1016/j. socscimed.2012.04.014.

Wallerstein I. (2000). The Modern World System. International Sociology 15: 249-265.

Willadssen, B. (2014). Arbeidsmiljø og HMS-arbeid: integrasjon, problemløsning, utvikling [Working Environment and OHS-work: Integration, Problemsolving and Development]. Oslo: Gyldendal akademisk. 